\title{
Pengaruh Interval Kelahiran Bayi Terhadap Kejadian Stunting pada Balita
}

Kiki Dwi Qori Ayatulloh, Harsono Salimo, Sri Martuti

Bagian Ilmu Kesehatan Anak Fakultas Kedokteran Universitas Sebelas Maret/RSUD Dr. Moewardi, Surakarta

Latar belakang. Stunting diartikan panjang badan atau tinggi badan terhadap usia kurang dari -2 standar deviasi kurva pertumbuhan WHO 2006. Banyak faktor yang menyebabkan stunting, di antaranya nutrisi, lingkungan, sosial ekonomi, termasuk interval kelahiran.

Tujuan. Penelitian ini bertujuan menganalisis pengaruh kedekatan interval kelahiran terhadap kejadian stunting.

Metode. Penelitian ini bersifat analitikobservasional secara potong lintang. Subjek penelitian adalah balita yang berkunjung ke Puskesmas Mojogedang. Data didapatkan dari anamnesis orangtua dan tinggi badan balita yang diplotkan pada kurva WHO. Data dianilisis dengan chi square dan analisis regresi logistik.

Hasil. Seratus limapuluh delapan balita mengikuti penelitian dengan proporsi $22,2 \%$ anak stunting dan $77,8 \%$ anak tidak stunting. Pendidikan ibu, IMT ibu, dan pemberian ASI eksklusif tidak berpengaruh dalam penelitian ini. Penghasilan rendah ( $\mathrm{p}=0,007$ dengan OR=3,286 dan $\mathrm{CI} ; 1,383-7,806$ ), asupan kalori kurang ( $\mathrm{p}=0,004$ dengan $\mathrm{OR}=4,887$ dan $\mathrm{CI} ; 1,675-14,256)$, dan interval kelahiran $<36$ bulan ( $\mathrm{p}=0,035$ dengan $\mathrm{OR}=2,479$ dan $\mathrm{CI} ; 1,064-5,774)$ memengaruhi kejadian stunting.

Kesimpulan. Interval kelahiran bayi memengaruhi kejadian stunting pada balita. Sari Pediatri 2022;23(5):306-12

Kata kunci: stunting, interval kelahiran, balita

\section{The Effect of The Birth Interval on The Incidence of Stunting in Children Under Five Years}

Kiki Dwi Qori Ayatulloh, Harsono Salimo, Sri Martuti

Background. Stunting is defined as length or height for age less than -2 standard deviation of the WHO growth curve 2006. Many factors cause stunting including nutrition, environment, socio-economy, including birth interval.

Objective. The aim of this study is to analyze the effect of the proximity of the birth interval on the incidence of stunting.

Methods. This research is analytic observational cross sectional study. The research subjects were toddlers who visited the Mojogedang Community Health Center. The data were obtained from the parental history and height of the children which were plotted on the WHO curve. Data were analyzed by chi square and logistic regression analysis

Results. A total of 158 children participated in this studywith the proportion of $22.2 \%$ stunting and $77.8 \%$ non-stunting. Maternal education, maternal BMI and exclusive breastfeeding did not affect this study. Low income ( $\mathrm{p}=0.007$ with OR=3.286 and CI; 1.383-7.806), less calorie intake ( $\mathrm{p}=0.004$ with $\mathrm{OR}=4.887$ and CI; 1.675-14.256), and birth interval $<36$ months ( $\mathrm{p}=0.035$ with OR=2,479 and CI; 1,064-5,774) affect the incidence of stunting.

Conclusions. There were a significant effect of birth interval on the incidence of stunting. Sari Pediatri 2022;23(5):306-12

Keywords: stunting, birth interval, under 5 years

Alamat korespondensi: Kiki Dwi Qori Ayatulloh. Departemen Ilmu Kesehatan Anak Univesitas Sebelas Maret Surakarta. Jl. Kolonel Sutarto No.132, Jebres, Kec. Jebres, Kota Surakarta, Jawa Tengah 57126. Email: kiki.ayatulloh@gmail.com 
S tunting merupakan masalah nutrisi yang dialami oleh banyak negara, tidak terkecuali Indonesia. Stunting menunjukan adanya masalah gizi yang bersifat kronis dengan berbagai faktor yang memengaruhi nya serta memberikan dampak jangka pendek dan jangka panjang bagi masa depan seorang anak. Stunting berpotensi menjadi lingkaran setan yang dapat terjadi lintas generasi. ${ }^{1,2}$

Proses stunting dapat terjadi sejak dalam kandungan. Oleh karena itu, nutrisi ibu hamil dan remaja putri sangat memengaruhi kejadian ini. ${ }^{2-7}$ Berdasarkan Rikesdas tahun 2018, kejadian kurang energi kronis pada wanita usia subur tahun 2018 sebesar 14,5\%, dengan proporsi terbesar terjadi pada kelompok usia 15-19 tahun. ${ }^{8}$ Adanya kondisi malnutrisi pada ibu akan memengaruhi nutrisi pada janin. Semakin dekat interval kelahiran antar bayi maka semakin besar kemungkinan terjadinya stunting, hal ini dikarenakan adanya deplesi nutrisi pada ibu. ${ }^{9-11}$

Pada kondisi hamil, peningkatan kebutuhan energi ibu sebesar $13 \%$, protein $54 \%$, dan vitamin-mineral bervariasi antara $0-50 \%$. Setelah melahirkan, ibu memasuki periode laktasi. Ibu membutuhkan asupan kalori yang lebih besar pada periode ini, yaitu ibu memerlukan kenaikan asupan energi sebesar 25\%, protein $54 \%$, vitamin dan mineral 0-93\%. Pada kondisi ini, ibu rentan mengalami deplesi nutrisi. Saat kondisi tersebut ibu mengalami kehamilan lagi, maka akan meningkatkan risiko terjadinya deplesi nutrisi ibu yang akan memengaruhi nutrisi janin yang dikandungnya. Kondisi deplesi nutrisi ibu terjadi terutama pada ibu yang mengalami kehamilan multipel dan ibu dengan interval kehamilan yang dekat. ${ }^{10-11}$

Interval kelahiran merupakan jarak antara kelahiran bayi sebelumnya dengan kelahiran bayi yang baru. Banyak penelitian yang mencari kapan waktu terbaik seorang ibu untuk kembali hamil. Beberapa penelitian mencari hubungan antara interval kelahiran dengan mortalitas ibu dan bayi, pertumbuhan bayi, perkembangan bayi dan dampaknya bagi keluarga tersebut. ${ }^{10}$

Dalam rangka mengurangi morbiditas dan mortalitas ibu dan bayi, WHO merekomendasikan birth to preganancy interval (jarak kelahiran bayi yang sebelumnya dengan awal kehamilan bayi yang selanjutnya) minimal $18-27$ bulan. ${ }^{12}$ Oleh karena itu, penulis menggunakan istilah interval kelahiran yang diperoleh dari birth to pregnancy 27 bulan ditambah dengan 9 bulan kehamilan, untuk mempermudah perhitungan diperoleh cut off 36 bulan.

Data penelitian tentang pengaruh interval kelahiran dengan kejadian stunting masih belum banyak dilakukan. Diharapkan, penelitian ini dapat menyajikan data tentang kejadian stunting pada balita dan menganalisis pengaruh interval kelahiran terhadap kejadian stunting masa balita.

\section{Metode}

Desain penelitian ini adalah observasional analitik dengan studi potong lintang yang dilakukan di Puskesmas Mojogedang I pada bulan Juni - Agustus 2020. Populasi adalah balita sehat yang berkunjung ke puskesmas pada kegiatan imunisasi. Pengambilan sampel dilakukan secara purposive sampling. Kriteria inklusi yaitu usia kurang dari sama dengan 60 bulan, anak dalam kondisi sehat, Ibu/keluarga bersedia mengisi kuesioner dan menandatangani lembar persetujuan penelitian. Sementara kriteria eksklusi yaitu balita yang memiliki penyakit infeksi kronis (seperti TBC), sedang menjalani kemoterapi, memiliki kelainan kongenital (seperti penyakit jantung bawaan, talasemia, osteogenesis imperfekta, sindrom tertentu), anak pertama, anak dengan riwayat kehamilan multipel (kembar). Penelitian ini telah memperoleh kelayakanetik dari Komite Etika Penelitian Kesehatan (KEPK) Rumah Sakit Dr. Moewardi, Surakarta dan izin dari Dinas Kesehatan Karanganyar.

Variabel bebas adalah interval kelahiran bayi, sedangkan angka kejadian stunting merupakan variabel terikat. Variabel lain yang juga diperhitungkan dalam penelitian ini adalah penghasilan keluarga, tingkat pendidikan ibu, pemberian ASI eksklusif, kecukupan asupan kalori, BMI ibu saat awal kehamilan.

Penelitian dimulai dengan penjelasan prosedur penelitian dan persetujuan pengambilan data oleh ibu/pengasuh. Data mengenai interval kelahiran, penghasilan keluarga, pendidikan ibu, pemberian ASI eksklusif, didapatkan dari anamnesis yang dilakukan kepada ibu/pengasuh. Data mengenai kecukupan asupan kalori didapat melalui recall diet 1x24 jam, kemudian dimasukkan kedalam aplikasi nutrisurvey, kalori yang didapatkan dibandingkan dengan kebutuhan RDA, dikatakan cukup bila anak mengkonsumsi kalori sebanyak $\geq 90 \%$ AKG. Angka BMI ibu saat awal kehamilan didapatkan dari catatan 
pada buku KIA. Pengukuran antropometri digunakan kurva pertumbuhan WHO 2006. Kemudian balita dikelompokkan menjadi stunting dan tidak stunting. Analisis hubungan dua variabel digunakan chi square, apabila didapatkan nilai $p<0,25$, maka data tersebut dianalisis multivariat regresi logistik.

\section{Hasil}

Sejumlah 158 anak, terdiri atas 35 anak stunting dan 123 tidak stunting. proporsi jenis kelamin hampir sama antara laki-laki dan perempuan (Tabel 1). Tingkat pendidikan ibu sebagian besar baik $(91,1 \%)$, yaitu ibu berpendidikan SMA ke atas dan sebagian besar ibu memberikan ASI eksklusif (71,5\%). Kondisi sosial ekonomi subjek sebagian besar baik, nampak pada data penghasilan orang tua rata-rata diatas UMR $(67,7 \%)$ dan nilai IMT ibu saat awal kehamilan sebagian besar normal $(91,3 \%)$. Interval kelahiran pada sampel sebagian besar lebih dari 36 bulan $(67,7 \%)$.

Tabel 1. Karakteristik dasar subjek penelitian $(\mathrm{n}=158)$

\begin{tabular}{|c|c|}
\hline Variabel & Hasil \\
\hline \multicolumn{2}{|l|}{ Jenis kelamin (\%) } \\
\hline Laki-laki & $80(50,6)$ \\
\hline Perempuan & $78(49,4)$ \\
\hline \multicolumn{2}{|c|}{ Pendidikan ibu (\%) } \\
\hline SD dan SMP & $14(8,9)$ \\
\hline SMA Ke atas & $144(91,1)$ \\
\hline \multicolumn{2}{|l|}{ ASI Eksklusif (\%) } \\
\hline $\mathrm{Ya}$ & $113(71,5)$ \\
\hline Tidak & $45(28,5)$ \\
\hline \multicolumn{2}{|c|}{ IMT ibu saat hamil (\%) } \\
\hline Kurang & $9(5,7)$ \\
\hline Normal-lebih & $149(94,3)$ \\
\hline \multicolumn{2}{|c|}{ Penghasilan keluarga (\%) } \\
\hline$<\mathrm{UMR}$ & $57(36,1)$ \\
\hline$\geq \mathrm{UMR}$ & $101(63,9)$ \\
\hline \multicolumn{2}{|c|}{ Kecukupan asupan kalori (\%) } \\
\hline$<90 \%$ & $51(32,3)$ \\
\hline$\geq 90 \%$ & $107(67,7)$ \\
\hline \multicolumn{2}{|c|}{ Interval kelahiran (\%, bulan) } \\
\hline$<36$ & $51(32,3)$ \\
\hline$\geq 36$ & $107(67,7)$ \\
\hline \multicolumn{2}{|l|}{ Stunting (\%) } \\
\hline Stunting & $35(22,2)$ \\
\hline Normal & $123(77,8)$ \\
\hline
\end{tabular}

Hasil analisis bivariat antara interval kelahiran dan variabel lain terhadap kejadian stunting tertera pada Tabel 2. Kecukupan asupan kalori dan penghasilan keluarga memiliki nilai yang signifikan dengan nilai $\mathrm{p}=0,019, \mathrm{p}=0,032$ dan $\mathrm{p}<0,001$ sehingga ketiga faktor tersebut dimasukkan dalam analisis regresi logistik.

\section{Pembahasan}

Pada kelompok anak stunting, subjek perempuan lebih besar dibandingkan anak laki-laki, tetapi hal ini tidak berbeda bagi kejadian stunting. Hal ini sesuai dengan hasil penelitian Gribble dkk, ${ }^{17}$ yang melaporkan bahwa tidak ada perbedaan faktor jenis kelamin pada kejadian stunting, yang juga sejalan dengan penelitian Nojomi $\mathrm{dkk}^{13}$ dan Pramod dkk. ${ }^{14}$ Sementara menurut Mushtaq $\mathrm{dkk}^{15}$ dan Matsungo dkk, ${ }^{16}$ jenis kelamin laki-laki lebih sering terjadi stunting daripada perempuan, hal ini dikarenakan pola pertumbuhan yang berbeda.'

Penelitian kami tidak mendapatkan perbedaan kejadian stunting yang dikaitkan dengan faktor pendidikan ibu. Hal ini sesuai dengan penelitian oleh Matsungo $\mathrm{dkk}^{16}$ yang melaporkan tidak ada perbedaan kejadian stunting antara ibu dengan masa pendidikan kurang dari 10 tahun atau lebih. Kemajuan teknologi dan kemudahan akses pengetahuan pola hidup sehat, baik melalui media televisi, penyuluhan di posyandu, leaflet di lokasi pelayanan kesehatan, telah memberikan pengetahuan yang baik kepada ibu. Gribble dkk ${ }^{17}$ melaporkan angka kejadian stunting menurun pada anak dari ibu dengan pendidikan di atas 10 tahun dibandingkan anak dari ibu yang mendapat pendidikan 6 tahun. Penelitian Pramod dkk, ${ }^{14}$ melaporkan bahwa faktor pendidikan ibu lebih dari 5 tahun memiliki faktor protektif terhadap kejadian stunting. Dengan asumsi bahwa, ibu dengan pengetahuan baik akan memberikan makanan yang berkualitas untuk anak dan perbaikan dalam hal perawatan anak.

Pemberian ASI eksklusif merupakan salah satu faktor protektif terhadap kejadian stunting. Menurut Fatemi dkk, ${ }^{18}$ terdapat perbedaan pada riwayat pemberian ASI eksklusif dan dilanjutkan sampai 24 bulan terhadap kejadian stunting. Sementara menurut penelitian kami tidak terdapat perbedaan dalam hal pemberian ASI eksklusif antara anak yang stunting dan anak normal. Hal ini sejalan dengan penelitian Gribble $\mathrm{dkk}^{17}$ dan Rusmil dkk, ${ }^{1}$ tidak terdapat hubungan antara 
Kiki Dwi Qori Ayatulloh dkk: Pengaruh interval kelahiran bayi terhadap kejadian stunting pada balita

Tabel 2. Analisis bivariat antara interval kelahiran dan variabel perancu terhadap kejadian stunting

\begin{tabular}{|c|c|c|c|c|}
\hline Variabel & $\begin{array}{c}\text { Stunting } \\
\mathrm{n}=35\end{array}$ & $\begin{array}{c}\text { Normal } \\
\mathrm{n}=123\end{array}$ & OR $(95 \% \mathrm{CI})$ & $\mathrm{p}$ \\
\hline \multicolumn{5}{|l|}{ Jenis kelamin (\%) } \\
\hline Laki-laki & $16(45,7)$ & $64(52,0)$ & $0,776(0,366-1,649)$ & 0,509 \\
\hline Perempuan & $19(54,3)$ & $59(48,0)$ & & \\
\hline \multicolumn{5}{|l|}{ Pendidikan ibu (\%) } \\
\hline SD dan SMP & $1(2,9)$ & $13(10,6)$ & $0,249(0,031-1,972)$ & 0,308 \\
\hline SMA ke atas & $34(97,1)$ & $110(89,4)$ & & \\
\hline \multicolumn{5}{|l|}{ ASI eksklusif (\%) } \\
\hline Ya & $24(68,6)$ & $89(72,4)$ & $0,834(0,369-1,844)$ & 0,661 \\
\hline Tidak & $11(31,4)$ & $34(27,6)$ & & \\
\hline \multicolumn{5}{|l|}{ IMT ibu (\%) } \\
\hline Kurang & $2(5,7)$ & $7(5,7)$ & $1,004(0,119-5,067)$ & 1,000 \\
\hline Normal atau lebih & $33(94,3)$ & $116(94,3)$ & & \\
\hline \multicolumn{5}{|c|}{ Penghasilan keluarga (\%) } \\
\hline$<\mathrm{UMR}$ & $18(51,4)$ & $39(31,7)$ & $2,281(1,062-4,896)$ & $0,032^{*}$ \\
\hline$\geq \mathrm{UMR}$ & $17(48,6)$ & $84(68,3)$ & & \\
\hline \multicolumn{5}{|c|}{ Kecukupan asupan kalori (\%) } \\
\hline$<90 \%$ & $20(57,1)$ & $31(25,2)$ & $3,957(1,808-8,662)$ & $<0,001^{* *}$ \\
\hline$>90 \%$ & $15(42,9)$ & $92(74,8)$ & & \\
\hline \multicolumn{5}{|c|}{ Interval kelahiran (\%, bulan) } \\
\hline$<36$ bulan & $17(48,6)$ & $34(27,6)$ & $2,472(1,143-5,349)$ & $0,019^{*}$ \\
\hline$\geq 36$ bulan & $18(51,4 \%)$ & $89(72,4 \%)$ & & \\
\hline
\end{tabular}

Tabel 3. Analisis multivariat antara interval kelahiran dan variabel perancu terhadap stunting

\begin{tabular}{|c|c|c|}
\hline Variabel & OR $(95 \% \mathrm{CI})$ & $\mathrm{p}$ \\
\hline Interval kelahiran (<36 bulan) & $2,479(1,064-5,774)$ & $0,035^{*}$ \\
\hline \multicolumn{3}{|l|}{ Variabel perancu } \\
\hline Penghasilan (<UMR) & $3,286(1,383-7,806)$ & $0,007^{* *}$ \\
\hline Cakupan kalori $(<90 \%)$ & $4,887(1,675-14,256)$ & $0,004^{* *}$ \\
\hline
\end{tabular}

pemberian ASI eksklusif dengan kejadian stunting. Hasil yang sama juga ditunjukkan penelitian Matsungo $\mathrm{dkk}^{16}$ di Afrika Selatan yang melaporkan bahwa waktu pemberian ASI eksklusif tidak memengaruhi kejadian stunting. Khan $\mathrm{dkk}^{19}$ melaporkan bahwa tidak terdapat hubungan antara pemberian ASI eksklusif dengan kejadian stunting, wasting, maupun underweight. Subjek penelitian ini berusia di bawah lima tahun, untuk usia 0-6 bulan kebutuhan gizi anak tercukupi oleh ASI saja. Untuk usia di atas 6-24 bulan, pemenuhan kebutuhan nutrisi anak lebih besar didapatkan dari MPASI dibandingkan dari ASI. Dengan demikian bila kebutuhan nutrisi ini tidak terpenuhi, hal ini meningkatkan risiko stunting pada balita. Produksi ASI juga dipengaruhi oleh nutrisi ibu, semakin baik nutrisi ibu maka semakin baik produksi ASI-nya. Air susu ibu memiliki banyak efek positif bagi anak, seperti meningkatkan imunitas anak. Pemberian ASI memiliki efek protektif terhadap kejadian infeksi anak, seperti menurunkan kejadian diare, infeksi saluran pernafasan 
akut, dan demam terutama di negara berkembang dengan kebersihan dan pengetahuan mengenai MPASI kurang. ${ }^{19}$ Infeksi berulang dapat menjadi salah satu penyebab stunting sehingga pemberian ASI eksklusif masih mungkin menjadi faktor protektif terhadap kejadian stunting melalui mekanisme peningkatan imunitas anak. Namun, pada penelitian kami tidak menunjukkan perbedaan kejadian stunting pada pemberian ASI eksklusif atau tidak.

Penelitian kami tidak mendapatkan perbedaan IMT ibu saat awal kehamilan antara anak yang stunting dengan anak normal. Hal ini sesuai dengan penelitian Young $\mathrm{dkk}^{20}$ bahwa tidak terdapat perbedaan kejadian stunting pada ibu dengan IMT rendah (IMT $<18,5$ ) atau lebih. Namun, jika BMI $<17 \mathrm{~kg} / \mathrm{m} 2$, hal tersebut akan meningkatkan risiko stunting pada anak sebesar 1,3 kali. Tiap kenaikan $1 \mathrm{~cm}$ tinggi ibu dan $1 \mathrm{~kg}$ berat badan ibu akan meningkatkan $0,2 \mathrm{~cm}$ tinggi bayi dan $0,3 \mathrm{~kg}$ berat badan bayi.

Stunting dipengaruhi oleh banyak faktor, di antaranya faktor sosial ekonomi, demografi, infeksi, dan nutrisi. Penelitian kami mendapatkan perbedaan dalam hal penghasilan keluarga antara anak yang stunting dengan anak normal. Menurut penelitian Pramod $\mathrm{dkk}^{14}$ dan Fatemi $\mathrm{dkk}^{18}$ penghasilan keluarga tidak memengaruhi kejadian stunting pada anak.' Akan tetapi, menurut penelitian Aerts dkk, ${ }^{21}$ anak dari keluarga dengan penghasilan di bawah UMR berisiko terjadi stunting 4 kali lebih besar dari pada anak dengan penghasilan keluarga di atas UMR. Penelitian ini melaporkan bahwa keluarga dengan penghasilan rendah memiliki kesulitan dalam menyediakan bahan makanan yang berkualitas dan sanitasi yang baik sehingga asupan nutrisi menjadi kurang dan anak cenderung mudah mengalami infeksi. Pada penelitian lain, Utami $\mathrm{dkk}^{22}$ melaporkan bahwa penghasilan keluarga berkaitan langsung dengan ketersediaan pangan bagi anggota keluarga. Keluarga dengan pendapatan rendah maka akan berisiko 3,25 kali lebih tinggi untuk terjadi stunting. Sementara Gribble dkk ${ }^{15}$ dan Mushtaq dkk, ${ }^{17}$ melaporkan bahwa faktor kondisi sosial ekonomi dan demografi tempat tinggal memengaruhi kejadian stunting, angka stunting lebih tinggi pada kondisi sosial ekonomi rendah dan tempat tinggal di pedesaan, hal ini dikarenakan kesulitan akses mencapai penyediaan bahan makanan berkualitas. Penelitian kami mendapatkan anak dengan orang tua berpenghasilan di bawah UMR be risiko terjadinya stunting 3,3 kali lebih besar dari anak dari keluarga berpenghasilan di atas UMR.
Faktor kecukupan asupan nutrisi juga memengaruhi kejadian stunting. Anak dengan asupan kalori yang kurang berisiko stunting lebih besar 4,8 kali dibandingkan anak dengan asupan nutrisi cukup. Menurut penelitian Fatemi $\mathrm{dkk}^{18}$ dan Esfarjani dkk, ${ }^{23}$ diet tinggi protein dapat menurunkan risiko stunting pada anak. Pada penelitian Alshammari $\mathrm{dkk},{ }^{24}$ melaporkan bahwa terdapat perbedaan dalam asupan energi, asupan zink, vitamin, dan kalsium. Anak stunting memiliki asupan yang lebih rendah dari pada anak normal. Menurut penelitian Utami $\mathrm{dkk}^{22}$ anak dengan asupan protein kurang dari AKG berisiko stunting lebih besar 10,36 kali dibandingkan anak dengan asupan protein cukup. Akan tetapi, penelitian Ernalia dkk, ${ }^{25}$ melaporkan bahwa perbedaan asupan kalori tidak memengaruhi kejadian stunting, tetapi rendahnya asupan protein berperan dalam meningkatkan kejadian stunting pada anak. Heijden $\mathrm{dkk}^{26}$ melaporkan bahwa anak stunting memiliki asupan kalori lebih rendah dari pada anak yang tidak stunting. Terdapat perbedaan asupan nutrisi sebesar 80-100 kkal antara anak yang stunting dan tidak stunting. Adanya kekurangan ini menyebabkan adanya penurunan aktifitas pertumbuhan sel pada anak, yang mengakibatkan stunting. Pada penelitian ini, fakor kecukupan asupan nutrisi memengaruhi kejadian stunting.

Hasil penelitian kami sejalan dengan penelitian Azmy $\mathrm{dkk}^{27}$ yang melaporkan bahwa asupan nutrisi memengaruhi status gizi. Anak dengan kekurangan asupan kalori, berisiko 4,048 kali lebih besar menderita stunting. Bahan makanan mengandung protein, karbohidrat, dan lemak akan dirubah menjadi energi untuk metabolisme dan pertumbuhan sel sehingga sel akan tumbuh dan berkembang dengan baik. Apabila kekurangan nutrisi, pertumbuhan akan terhambat. Pada penelitian tersebut menunjukkan bahwa konsumsi zink pada anak stunting $13 \mathrm{mg}$ lebih rendah daripada anak normal. Zink berperan sebagai mikronutrien untuk membantu metabolisme dan pertumbuhan sel sehingga kekurangan zink akan memengaruhi pertumbuhan anak.

Penelitian kami memberikan gambaran adanya pengaruh interval kelahiran terhadap kejadian stunting. Anak dengan interval kelahiran kurang dari 36 bulan berisiko stunting 2,47 kali lebih besar dari pada anak dengan interval kehamilan $\geq 36$ bulan. Badan kesehatan dunia WHO menyarankan adanya penjarangan kelahiran, yaitu memulai kehamilan saat jarak dari kelahiran sebelumnya minimal 24 bulan. Menurut penelitian Aerts dkk, ${ }^{21}$ anak berisiko stunting lebih 
besar pada interval kelahiran kurang dari 24 bulan dan memiliki banyak anak (lebih dari 3 dalam sebuah keluarga). Hal ini dikarenakan adanya masalah dalam merawat anak, masalah penyediaan makanan berkualitas dan infeksi. Menurut penelitian Gribble dkk, ${ }^{17}$ interval kelahiran berperan dalam kejadian stunting. Risiko kejadian stunting menurun pada interval kelahiran yang panjang. Menurut penelitian Shahjada, ${ }^{28}$ angka kejadian underweight, wasted, and stunted menurun sering dengan bertambah lamanya interval kelahiran. Pada penelitian tersebut dinyatakan angka kejadian underweight, wasted, and stunted pada interval kelahiran kurang dari 24 bulan sebesar $57,21 \%$, 42,78\%, dan 51,03\%, sedangkan pada interval kelahiran di atas 48 bulan sebesar 29,62\%, 22,22\% dan 25,92\%.Menurut penelitian Pramod $\mathrm{dkk}^{14}$ tidak terdapat perbedaan kejadian stunting pada interval kelahiran kurang dari 24 bulan dengan lebih dari 24 bulan.

Pada kondisi hamil, seorang ibu mengalami peningkatan kebutuhan nutrisi, saat memasuki peridode laktasi, ibu membutuhkan lebih banyak tambahan nutrisi. Apabila ibu yang belum pulih kondisi nutrisinya ini mengalami kehamilan, maka ibu semakin mengalami kekurangan nutrisi sehingga terjadi maternal deplesion syndrome, yang akan menurunkan nutrisi janin yang dikandungnya. Menurut penelitian Dewey dkk, ${ }^{11}$ interval antar kelahiran sebesar lebih dari atau sama dengan 36 bulan dapat menurunkan risiko kejadian stunting sebesar 10\%-50\% pada bayi yang dikandungnya.

Hasil penelitian kami menunjukkan bahwa faktor kecukupan asupan kalori, penghasilan keluarga dan interval kelahiran dapat memengaruhi kejadian stunting. Anak yang lahir dengan interval kelahiran yang pendek ( $<36$ bulan) memiliki risiko menjadi stunting dikemudian hari, yang dikarenakan kurangnya nutrisi sejak dalam kandungan serta didukung dengan kurangnya kecukupan asupan kalori dan sosial ekonomi yang rendah. Terjadinya stunting dipengaruhi oleh banyak faktor. Interval kelahiran yang pendek memberikan dampak yang luas, selain berkurangnya nutrisi anak sejak dalam kandungan, interval kelahiran yang pendek juga memberikan masalah dalam perawatan bayi, infeksi antar bayi, serta pada keluarga dengan penghasilan rendah akan mengakibatkan kesulitan dalam menyediakan bahan makanan yang bergizi. Oleh sebab itu, menjarangkan kelahiran dengan interval kelahiran $\geq 36$ bulan dapat mengurangi kejadian stunting pada anak.
Keterbatasan pada penelitian kami adalah kurang sempitnya batasan pengelompokan interval kelahiran terhadap kejadian stunting. Faktor infeksi, budaya, jumlah anak dan sanitasi juga tidak diperhitungkan dalam penelitian ini.

\section{Kesimpulan}

Hasil penelitian ini menunjukkan bahwa anak dengan interval kelahiran kurang dari 36 bulan berisiko stunting dua kali lebih besar daripada anak dengan interval kelahiran $\geq 36$ bulan. Sementara anak dengan asupan kalori yang kurang berisiko stunting empat kali lebih besar dibandingkan anak dengan asupan kalori cukup. Untuk anak dengan penghasilan keluarga di bawah UMR berisiko stunting lebih besar 3,286 kali dibandingkan anak dengan penghasilan keluarga di atas UMR.

\section{Daftar pustaka}

1. Rusmil VK, Ikhsani R, Dhamayanti M, Hafsah T. Hubungan perilaku ibu dalam praktik pemberian makan pada anak usia 12-23 bulan dengan kejadian stunting di wilayah kerja puskesmas Jatinangor. Sari Pediatri 2019;20:366-74.

2. Hayati AW, Hardinsyah, Jalal F, Madanijah S, Briawan D. Faktor-faktor risiko stunting anak 0-23 bulan. IPB Jurnal Forum Pascasarjana 2013; 36:73-93.

3. Martorell, et al. Intergenerational influences on child growth and undernutrition. Paediatrics and perinatal epidemiology 2012;302-14.

4. McGregor GS, Cheung YB, Cueto S, Glewwe P, Richter L, Strupp B. International child development steering group: Developmental potential in the first 5 years for children in developing countries. The lancet 2007;369:60-70.

5. Hendarto A dan Sjarif DR. Antropometri anak dan remaja. Dalam: Sjarif DR, Lestari ED, Mexitalia M, Nasar SS, penyunting. Buku ajar nutrisi pediatrik dan penyakit metabolik. Jilid I revisi. Jakarta: Badan penerbit IDAI;2014.h.25-35.

6. Badan Penelitian dan Pengembangan Kesehatan KKRI. Laporan Hasil Riset Kesehatan Dasar tahun 2013, Riskesdas. Edisi pertama. Jakarta:CV Kiat Nusa; 2014.h.386-415.

7. Parks EP, Maqbool A, Shaikhkhalil A, dkk. Nutritional Requirements. Dalam: Kliegman RM, Stanton BF, Geme JW, Schor NF, Behrman RE, penyunting. Nelson text book of pediatrics. Edisi 20. Philadelphia: Elseviere; 2016.h.268-86.

8. Badan Penelitian dan Pengembangan Kesehatan KKRI. Laporan Hasil Riset Kesehatan Dasar tahun 2018, Riskesdas. Jakarta;2019. 
9. Department of nutrition for health and development, World Health Organization. Global nutritional target 2025: Stunting policy brief. Switzerland: World Health Organization;2017.

10. Bigiu N, Pandi B, Dimienescu O, Pascu A, Samota I, Ples L. Maternal depletion syndrome. Gineco eu 2015;11:98-103.

11. Dewey KG, Cohen RJ. Does birth spacing affect maternal or child nutritional status? A systematic literature review. Plos One 2007:151-73.

12. Department of Making Pregnancy Safer dan Department Reproductive Health and Research, World Health Organization. Report of a WHO technical consultation on birth spacing. Geneva, Switzerland: WHO; 2005.

13. Nojomi N, Kafashi A\& Najmabadi S. Study of frequency of malnutrition risk factors in under 5 years children in Karaj, 2001-2002. Razi J Med Sci 2003;10:123-30.

14. Pramod SG, Nair M, Grubesic RB. Factors associated with underweight and stunting among children in rural Terai of eastern Nepal. Asia Pac J Pub Health 2009;21:144-52.

15. Mushtaq MU, Gull S, Khurshid U, Shahid U, Shad MA, Siddiqui AM. prevalence and socio-demographic correlates of stunting and thinness among Pakistani primary school children. BMC Pub Health 2011,11:790.

16. Matsungo TM, Kruger HS, Faber M, Rothman M, Smuts $\mathrm{CM}$. The prevalence and factors associated with stunting among infants aged 6 months in a peri-urban South African community. Public Health Nutr 2017;20:3209-18.

17. Gribble JN, Murray NJ, Menotti EP. Original Article Reconsidering childhood undernutrition : can birth spacing make a difference? An analysis of the 2002 - 2003 El Salvador National Family Health Survey 2008;5:49-63.

18. Fatemi MJ, Fararouei M, Moravej H, Mostafa Dianatinasab M. Stunting and its associated factors among 6-7-year-old children in Southern Iran: a nested case-control study. Pub
Health Nutr 2018;22:1-8.

19. Khan MN, Islam MM. Effect of exclusive breastfeeding on selected adverse health and nutritional outcomes: a nationally representative study. BMC Pub Health 2017;17:1-7.

20. Young MF, Nguyen PH, Cassanova IG, Addow OY, Tran LM. Role of maternal preconception nutrition on offspring growth and risk of stunting across the first 1000 days in Vietnam: a prospective cohort study. Plos one 2018;13: e0203201.

21. Aerts D, Drachler MDL, Giuglianil ER. Determinants of growth retardation in southern Brazil. Cadernos de Saude Publica. Rio de Janeiro 2004;20:1182-90.

22. Utami D, Indarto D, Dewi YLR. The effect of nutrient intake and socioeconomic factor toward stunting incidence among primary school students in Surakarta. J Epidemiol Pub Health 2017;2:1-10.

23. Esfarjani F, Roustaee R, Nasrabadi FM, Esmaillzadeh A. Major dietary patterns in relation to stunting among children in Tehran, Iran. J Health Popul Nutr 2013;31:202-10.

24. Alshammari E, Suneetha E, Adnan M, Khan S,Alazzeh A. Growth profile and its association with nutrient intake and dietary patterns among children and adolescents in Hail region of Saudi Arabia. BioMed Res Int 2017;5740851:9.

25. Heijden LJM, Hautvast JLA, Luneta AK, Staveren WA, Tolboom JJM, Gastel SM. Food consumption of young stunted and non-stunted children inrural Zambia. Eur J Clin Nutr 1999;53:50-9.

26. Azmy U dan Mundiastuti L. Konsumsi zat gizi pada balita stunting dan non-stunting di Kabupaten Bangkalan. Amerta Nutr 2018;2:292-8.

27. Shahjada A, Sharman BK, Mahashabde P, Bachhotiya A. Effects of birth interval on nutritional status of under five children in periurban area of Madhya Pradesh, India. Int J Med Sci Pub Health 2014;3:723-6. 